\title{
Pulmonary Function Test and Thoracic Computed Tomography in the Evaluation of Dyspnea in Patients with Goiter
}

\section{Guatrlı Olgularda Dispnenin Değerlendirilmesinde Solunum Fonksiyon Testi ve Toraks Bilgisayarlı Tomografi}

(D) Güler Özgül11, (D) Erkan Yavuz²

${ }^{1}$ University of Health Sciences Turkey, Bağcılar Training and Research Hospital, Clinic of Chest Diseases and Tuberculosis, İstanbul, Turkey 2University of Health Sciences Turkey, Bağcılar Training and Research Hospital, Clinic of General Surgery, İstanbul, Turkey

\section{Abstract}

Objective: The uses of flow volume loop (FVL) section of pulmonary function test (PFT) and thorax computed tomography (TCT) are examined in the evaluation of dyspnea, which is one of the leading symptoms of compression due to goiter.

Method: Thirty-six patients who were admitted to the Chest Diseases and Tuberculosis Clinic of University of Health Sciences Turkey, Bağcılar Training and Research Hospital between August 2019 and January 2020 with the complaint of dyspnea and who were diagnosed with goiter were enrolled in this prospective study. To determine the compression of the goiter on the trachea, PFT and TCT were performed in all cases. The patients were evaluated in terms of age, gender, smoking history, complaints, respiratory system physical examination findings, $F V L$, type of goiter, presence of TCT findings of external compression and deviation of trachea due to goiter. The degree of external compression on trachea according to the TCT were grouped as follows grade 0: No compression on the trachea, grade 1: Compression narrowing the tracheal lumen diameter less than 50\%, grade 2: Compression narrowing the tracheal lumen diameter more than $50 \%$. FVL in PFT was grouped as normal and upper airway obstruction (UAO).

Results: Twenty-six of the 36 cases were female (72.22\%). The median age was 54.50 (range, 32-80) years. When the location of the goiter was evaluated, it was found that $25(69.44 \%)$ of the cases had retrosternal goiter (RSG) and 11 (30.56\%) had cervical goiter (CG). In terms of FVL, $28(77.78 \%)$ were compatible with UAO and $8(22.22 \%)$ with normal condition. Tracheal deviation was detected in 18 (50\%) cases. External compression of trachea was detected in $28(77.78 \%)$ cases, grade 1 in 14 (38.89\%) cases and Grade 2 in 14 (38.89\%) cases. FVL was found to be

\section{Öz}

Amaç: Guatra bağlı basının önde gelen semptomlarından biri olan dispnenin değerlendirilmesinde solunum fonksiyon testindeki (SFT) akım volüm halkası $(\mathrm{AVH})$ ve toraks bilgisayarlı tomografinin (TBT) kullanımının değerlendirilmesi amaçlandı.

Yöntem: Ağustos 2019-Ocak 2020 tarihleri arasında Sağlık Bilimleri Üniversitesi Bağcılar Eğitim ve Araştırma Hastanesi Göğüs Hastalıkları ve Tüberküloz Kliniği'ne nefes darlığı şikayeti ile başvuran guatr tanılı 36 hasta bu prospektif çalışmaya alındı. Guatrın trakeaya basısını değerlendirmek için olguların tümüne SFT ve TBT yapıldı. Olgular yaş, cinsiyet, sigara öyküsü, şikayet, solunum sistemi muayene bulguları, $A V H$, guatr çeşidi, TBT'deki guatra bağlı trakea basısı ve deviasyonu açısından değerlendirildi. TBT'deki trakea basısı grade 0: Trakeaya bası yapmamış, grade 1: Trakea çapını \%50'den daha az daraltan bası, grade 2: Trakea çapını \%50'den daha fazla daraltan bası bulgusu şeklinde gruplandırıldı. SFT'deki AVH normal ve üst hava yolu obstrüksiyonu (ÜHYO) ile uyumlu olarak gruplandırıldı.

Bulgular: Çalışmadaki 36 olgunun 26'sı kadındı (\%72,22). Yaş ortalaması 54,50 (32-80 aralığında) yıldı. Guatr yerleşim yeri olarak 25'i $(\% 69,44)$ retrosternal guatr (RSG), 11'i $(\% 30,56)$ servikal guatrdı (SG). Akım volüm halkasına $(\mathrm{AVH})$ göre $28(\% 77,78)$ olgu ÜHYO ile uyumlu, $8(\% 22,22)$ olgu normal AVH ile uyumlu idi. Trakeal deviasyon 18 (\%50) olguda saptandı. Trakeal dış bası $28(\% 77,78)$ olguda saptanmıştı ve bunların 14'ü $(\% 38,89)$ grade 1, 14'ü $(\% 38,89)$ grade 2 şeklindeydi. AVH grade 0, 1, 2 grubunda sırasıyla \%25, \%85,71, \%100 oranlarında ÜHYO ile uyumlu saptandı ( $p=0,0001)$. Grade 0 grubunda normal AVH görülmesi grade 1 ve grade 2'ye göre istatistiksel olarak anlamlı oranda yüksek saptandı $(p=0,001)$. Guatr yerleşim yerine göre bakıldığında RSG

Address for Correspondence: Güler Özgül, University of Health Sciences Turkey, Bağcılar Training and Research Hospital, Clinic of Chest Diseases and Tuberculosis, ìstanbul, Turkey

E-mail: gulerozgul@hotmail.com ORCID: orcid.org/0000-0002-1048-1683 Received: 20.07.2020 Accepted: 28.10.2020

Cite this article as: Özgül G, Yavuz E. Pulmonary Function Test and Thoracic Computed Tomography in the Evaluation of Dyspnea in Patients with Goiter. Bagcilar Med Bull 2020;5(4):204-209

(C) Copyright 2020 by the Health Sciences University Turkey, Bagcilar Training and Research Hospital Bagcilar Medical Bulletin published by Galenos Publishing House. 


\section{Abstract}

compatible with $\mathrm{UAO}$ in grade 0,1 , and 2 with the percentages of $25 \%$, $85.71 \%$, and $100 \%$, respectively $(p=0.0001)$. Normal FVL appearance in Grade 0 group was statistically significant when compared to grade 1 and grade $2(p=0.001)$. According to goiter type, the compatibility of FVL with UAO was higher in the RSG group with a statistical significance $(p=0.002)$.

Conclusion: Although TCT is useful in evaluating the boundaries of the disease and surgical anatomy in patients with goiter, preoperatively, the FVL of the PFT should be considered as a priority over TCT to support the clinical correlation of dyspnea due to goiter.

Keywords: Dyspnea, flow volume loop, goiter, thoracic computed tomography

\section{Öz}

grubunda ÜHYO ile uyumlu AVH saptanması istatistiksel olarak anlamlı derecede yüksekdi $(p=0,002)$.

Sonuç: Guatrlı hastalarda her ne kadar TBT, hastalığın sınırlarını ve cerrahi anatomiyi değerlendirmede yararlı olsa da, guatra bağlı nefes darlığının klinik korelasyonunu desteklemek amaçlı preoperatif olarak SFT'nin AVH, TBT'den daha öncelikli olarak değerlendirilmelidir.

Anahtar kelimeler: Akım volüm halkası, dispne, guatr, toraks bilgisayarlı tomografi

\section{Introduction}

Goiter is defined as the growth of the thyroid gland in diffuse and nodular manner. The incidence of this disease, which is more common in women, is around $4-5 \%$ (1). It can be seen as cervical goiter (CG) or retrosternal goiter (RSG) according to the location. In RSG, more than $50 \%$ of the thyroid gland is under the sternal notch, in the mediastinum (2). Cough, dyspnea, stridor, choking sensation, and difficulty in swallowing, which are considered as goiter-related external compression symptoms, are also considered as surgical indications as well as the radiological findings of external compression in thoracic computerized tomography (TCT) (3).

TCT and pulmonary function tests (PFT) are used to evaluate external compression symptoms. Especially the flow volume loop (FVL) section in PFT helps the clinicians to evaluate the external compression of trachea. The $\mathrm{y}$-axis shows the flow, and the $\mathrm{X}$-axis shows the volume in FVL (4). In a correctly performed test, the two curves complement each other and appear convex (Figure 1, 2). In cases with upper airway obstruction (UAO) such as goiter, flattening is seen in the convex part of the loop (Figure 3, 4). If the external compression on the trachea causes restriction in airflow during inspiration or expiration, it is defined as variable airway obstruction. In fixed airway obstruction, airway diameter does not change throughout inspiration or expiration and the airflow is equally affected during the respiratory cycle (5).

The size of the thyroid gland, its characteristics, location, external compression on trachea, or its deviation can be examined with TCT; therefore, it plays an important role in preoperative evaluation.
In this study, we evaluated the use of PFT and TCT in cases with dyspnea related to the goiter. We compared the FVL in PFT and radiological findings in TCT.

\section{Materials and Methods}

The study was planned after the approval of the Ethics Committee of University of Health Sciences Turkey, Bağcllar Training and Research Hospital (ref number of: 2019.08.1.02.059/02.08.2019).

A total of 36 goiter cases, who were admitted to the Chest Diseases and Tuberculosis Clinic at University of Health Sciences Turkey, Bağcılar Training and Research Hospital between August 2019 and January 2020 with dyspnea, were enrolled in the study. Informed consents were taken from patients.

Patients with asthma, chronic obstructive pulmonary disease (COPD), acute bronchitis, acute upper respiratory tract infection, lung cancer and anemia, which can cause similar dyspnea symptoms and affect FVL, and those who failed in performing FVL were excluded from the study. All patients underwent PFT with a Mır-Mınıspır model handheld digital spirometry device. At least 3 respiratory maneuvers were performed by the PFT technician and the best FVL was recorded. PFTs were carried out according to the acceptability and repeatability criteria of ATS/ERS guidelines (6).

TCT was performed with Philips-Brilliance CT 64-Ds tomography device to evaluate the radiological findings of external compression and deviation of trachea due to goiter.

The cases were evaluated in terms of age, gender, smoking history, complaints, respiratory examination results, FVL, goiter type, radiological findings of external compression and deviation of trachea due to goiter. The external 
compression on trachea was grouped as grade $0,1,2$. Grade 0 : No external compression on the trachea, grade 1: External compression narrowing the trachea diameter by less than $50 \%$, grade 2: External compression narrowing the trachea diameter by more than $50 \%$.

\section{Statistical Analysis}

In this study, the NCSS (Number Cruncher Statistical System) 2007 Statistical Software (Utah, USA) package program was used for statistical analyses. In the evaluation of the data, the descriptive statistical methods (mean, standard deviation) were used as well as the Shapiro-Wilk normality test to test the distribution of the variables. The independent t-test was used in comparing the binary groups of variables with normal distribution and the chisquare test was used in the comparison of qualitative variables. The results were evaluated at the significance level of $\mathrm{p}<0.05$.
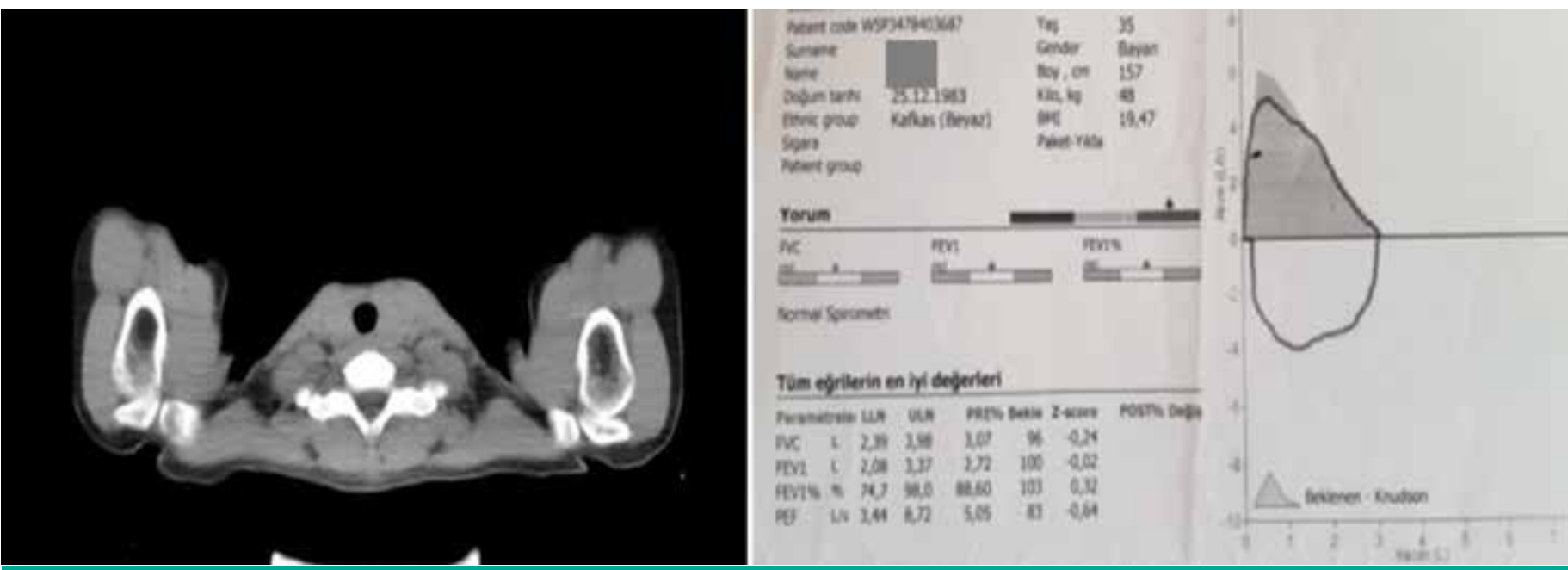

Figure 1, 2. Thoracic computerized tomography without an external compression on the trachea and normal flow volume loop of a 35-year-old female
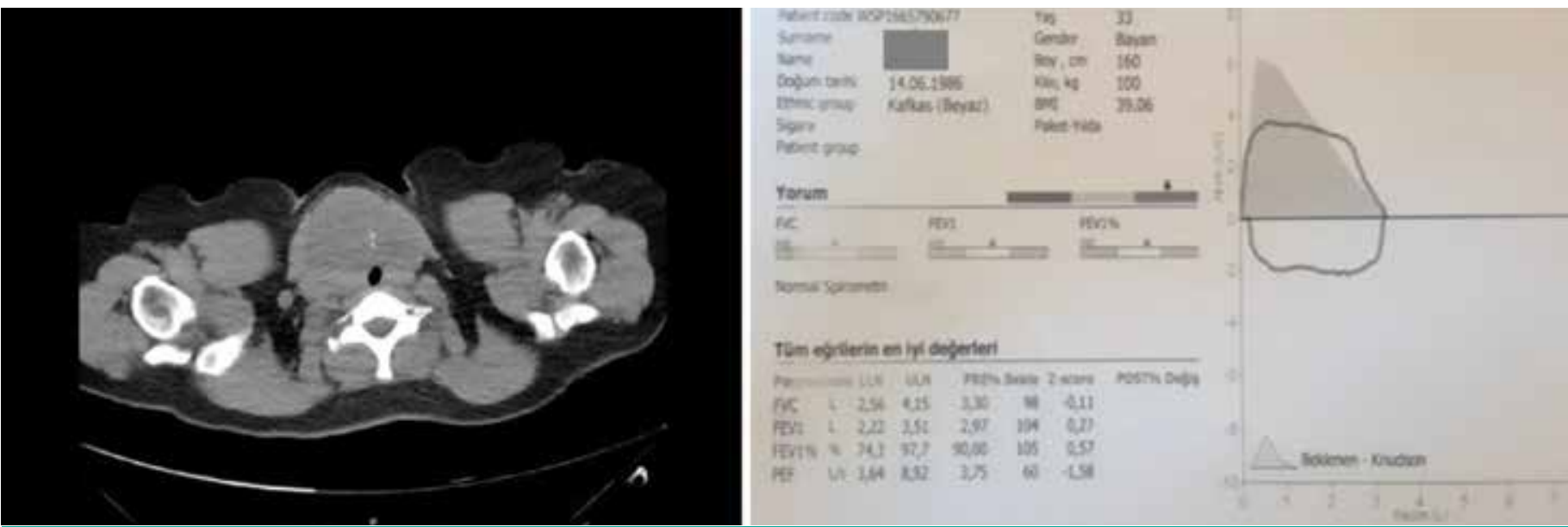

Figure 3, 4. Thoracic computerized tomography with an external compression on the trachea and flow volume loop compatible with upper airway obstruction of a 32-year-old female 
patients with UAO had fixed airway obstruction and 13 (36.11\%) had variable airway obstruction. Goiter-related tracheal deviation was detected in 18 (50\%) patients; 12 (66.67) had deviation to the right and 6 (33.33\%) to the left. External compression on the trachea was detected in 28 (77.78\%) patients, 14 (38.89\%) in the grade 1 group and 14 (38.89\%) in the grade 2 group. Radiological findings on TCT of RSG and CG groups are shown in Table 1.

Thirty of 36 patients were diagnosed histopathologically by performing goiter surgery or needle aspiration biopsy. A total of $24(80 \%)$ patients had benign and $6(20 \%)$ had malignant cytology, and finally 19 patients underwent surgery (52.78\%).

The relationship between FVL and external compression on the trachea (grade) is shown in Table 2 . In grades 0,1 , and 2, FVL was found to be compatible with UAO at the rates of $25 \%, 85.71 \%$, and $100 \%$, respectively ( $\mathrm{p}=0.0001$ ). When evaluated according to the goiter type, the UAO in the RSG group was higher than in the CG group with a statistical significance $(\mathrm{p}=0.002)$.

The percentage of narrowing in the tracheal lumen was $88 \%$ in the RSG group and $54.5 \%$ in the CG group, which was statistically significant $(\mathrm{p}=0.026)$. The external compression percentage in grade 2 level was $48 \%$ in RSG, which was higher than CG (18.2\%), but that was not statistically significant $(\mathrm{p}=0.06)$. Normal FVL in the grade 0 group was statistically significant when compared to grade 1 and grade $2(\mathrm{p}=0.001)$.

Table 1. Radiological findings of external compression on the trachea on thoracic computerized tomography in retrosternal goiter and cervical goiter

\begin{tabular}{llllll} 
& \multicolumn{7}{l}{ RSG* } & CGt \\
\hline & $\mathbf{n}$ & $\%$ & $\mathbf{n}$ & $\%$ & $\mathbf{p}$ \\
\hline Tracheal deviation & 15 & 60 & 3 & 27.3 & 0.070 \\
External compression on trachea & 22 & 88 & 6 & 54.6 & 0.026 \\
Grade 0 & 3 & 12 & 5 & 45.5 & - \\
Grade 1 & 10 & 40 & 4 & 36.4 & - \\
Grade 2 & 12 & 48 & 2 & 18.2 & 0.060 \\
\hline
\end{tabular}

*RSG: Retrosternal goiter, ${ }^{+}$CG: Cervical goiter

Table 2. The relationship between flow volume loop and grade of external compression on the trachea

\begin{tabular}{lccccccc} 
& \multicolumn{2}{c}{ Grade 0 } & \multicolumn{2}{c}{ Grade 1 } & \multicolumn{2}{c}{ Grade 2 } \\
\hline FVL* & $\mathbf{n}$ & $\%$ & $\mathbf{n}$ & $\%$ & $\mathbf{n}$ & $\%$ & $\mathbf{p}$ \\
\hline Normal & 6 & 75 & 2 & 14.29 & 0 & 0 & - \\
Compatible with UAO+ & 2 & 25 & 12 & 85.71 & 14 & 100 & 0.0001 \\
\hline
\end{tabular}

*FVL: Flow volume loop, +UAO: Upper airway obstruction

\section{Discussion}

TCT and less commonly PFT are generally used to evaluate dyspnea, which is one of the external compression symptoms related to goiter. However, TCT is a more expensive and invasive method when compared to PFT. The FVL in PFT is an easy and practical test that can be used to evaluate UAO due to external compression on the trachea caused by goiter. However, its disadvantages are that its diagnostic sensitivity is low in mild obstructions and the typical image of UAO is masked when coexisting diseases such as COPD and asthma are present $(7,8)$.

Albareda et al. (9) conducted a study and reported that $54 \%$ of RSG patients had symptoms due to external compression of goiter and $26 \%$ had FVL compatible with UAO. In terms of FVL, $24 \%$ of the cases had variable airway obstruction and $2 \%$ had fixed airway obstruction (9). In our study, all of the patients $(100 \%)$ had external compression symptoms; therefore, we found UAO at a higher rate of $92 \%$ (52\% of which was fixed, and $40 \%$ were variable airway obstructions in the RSG group). Regarding the higher number of cases with external compression of the trachea at grade 2 level, our UAO rates, especially fixed airway obstruction rates, may be higher.

In their study, Stevens et al. (10) examined the effect of FVL in deciding surgery in goiter patients. They found FVL to be normal in 33 of the 38 cases and abnormal in 5 . Two of the patients with abnormal FVL were compatible with external compression, and 3 were compatible with obstructive/ restrictive lung diseases. Seven of the 33 patients, who had normal FVL, underwent surgery (local compression, abnormal cytology, and grave's disease). They claimed that FVL had no effect on deciding on surgery. In this study, only 4 patients had dyspnea and 14 patients had combined symptoms (10). In our study, patients with co-existing obstructive/restrictive lung diseases were not included in the study because FVL could have been affected in this respect. All of the patients were symptomatic and had the complaint of dyspnea. Twenty eight (77.78\%) had abnormal but 8 (22.22\%) had normal FVL. FVL was compatible with UAO in these 28 cases. A total of 19 (52.78\%) patients underwent surgery. Six patients underwent surgery due to malignancy and other patients due to local compression on the trachea caused by goiter. In our study, we found that FVL had an effect on deciding surgery, especially in those who had local compression.

In Stevens et al.'s (10) study, 2 cases had external compression, 2 had tracheal deviation in TCT and FVL was 
normal in the cases with external compression. It may be due to the fact that the degree of the external compression was mild; no information was given in the study about it. In our study, since all of them were symptomatic, external compression was detected in $28(77.78 \%)$ and tracheal deviation in $18(50 \%)$ patients. FVL was compatible with UAO in 26 of those who had external compression, which was statistically significant. Such a difference between the two studies may be related to the greater number of patients with external compression.

Menon et al. (11) examined the prevalence of UAO and the correlation among clinical findings in goiter patients. They found radiological findings of external compression of the trachea in TCT in 9.3\% and FVL was compatible with UAO in PFT in $14.3 \%$ of patients, and no correlation was found between TCT findings and FVL. However, it should be addressed that $26.8 \%$ of the study population had RSG, and only $32 \%$ were symptomatic (11). In our study, $69.44 \%$ of the patients had RSG and all were symptomatic; therefore, the UAO rate was $77.78 \%$ and external compression rate was $77.78 \%$, which showed a higher rate and a correlation.

Thusoo et al. (12) detected radiological findings of tracheal deviation and/or external compression on chest X-rays in $32 \%$ of goiter patients. In their study, $40 \%$ of the population were symptomatic. They also detected FVL compatible with UAO in $60 \%$, the most common was variable airway obstruction. In contrast to our study, smokers were excluded in this study and only chest X-rays were used instead of TCT. It was found that $77.78 \%$ of our patients were compatible with UAO in FVL; $41.67 \%$ had fixed and $36.11 \%$ had variable airway obstruction (12). Since our rate of patients with RSG was higher, FVL compatible with UAO was also higher and the fixed airway obstruction was the most common obstruction type.

In previous studies, it was detected that $69-73 \%$ of patients with RSG and CG had tracheal deviation as the common radiological finding. External compression was relatively more common in patients with RSG [35 (73\%)] compared to the cases with SG [9 (58\%)]. Tracheal deviation was also radiologically detected in $50 \%$ and external compression in $77.78 \%$ of patients and the rates were similar to those reported in previous studies (13).

Patients with goiter should be referred to chest physicians in the presence of dyspnea, especially if they have RSG. After ruling out the other causes of dyspnea that are not related to external compression due to goiter, patients should be evaluated with PFT with priority, and then with TCT to see if there is an external compression or not. Depending on the degree of the external compression, surgery should be decided with a multi-disciplinary approach including the general surgeons. According to the interpretation of our study, a patient who has goiter and dyspnea should undergo PFT at first and then if FVL is normal, it should be considered as grade 0 or grade 1 . In this situation, there should be no need for further evaluations such as TCT. If FVL is compatible with UAO in grade 1 or grade 2 , then it is necessary to evaluate the patients with TCT. The presence of fixed airway obstruction especially with grade 2 level means that there is a surgical indication.

\section{Study Limitations}

A limitation of our study is that it involves a small number of patients so there is a need for further studies with larger study populations to support this issue.

\section{Conclusion}

Although TCT is preoperatively useful in evaluating the boundaries of the disease and surgical anatomy in patients with goiter, the FVL of the PFT should be considered as a priority over TBT to support the clinical correlation of dyspnea due to goiter.

\section{Ethics}

Ethics Committee Approval: The study was planned after the approval of the Ethics Committee of University of Health Sciences Turkey, Bağcılar Training and Research Hospital (reference number of: 2019.08.1.02.059/02.08.2019).

Informed Consent: Informed consents were taken from patients.

Peer-review: Externally peer-reviewed.

\section{Authorship Contributions}

Concept: E.Y., Design: E.Y., Data Collection or Processing: G.Ö., Analysis or Interpretation: G.Ö., Writing: E.Y., G.Ö.

Conflict of Interest: No conflict of interest was declared by the authors.

Financial Disclosure: The authors declared that this study has received no financial support.

\section{References}

1. Unal Y. Retrospective analysis of thyroidectomy cases in general surgery clinic of a training and research hospital. Med J Ankara Tr Res Hosp 2019;52:74-78. 
2. Yılmaz KB, Dogan L, Akıncı M, Cakmak H, Karaman N, Özaslan C, et al. Thyroid carcinoma in retrosternal goiter cases. Acta Oncol Tur 2010;43(1):8-12.

3. Hardy RG, Bliss RD, Lennard TWJ, Balasubramanian SP, Harrison BJ. Management of retrosternal goitres. Ann R Coll Surg Engl 2009;91(1):8-11.

4. Pellegrino R, Viegi G, Brusasco V, Crapo RO, Burgos F, Casaburi R, et al. Interpretative strategies for lung function tests. Eur Respir J 2005;26(5):948-968.

5. Kaminsky DA. Ch 2-Spirometry and Related Tests. Manual of Pulmonary Function Testing. 9th ed., Mosby Elsevier, 2009:36-89.

6. Miller MR, Crapo R, Hankinson J, Brusasco V, Burgos F, Casaburi $\mathrm{R}$, et al. General considerations for lung function testing ATS/ERS task force: standardisation of lung function testing. Eur Respir J 2005;26(1):153-161.

7. Ulubay G, Dilektaşlı AG, Börekci Ş, Yıldız Ö, Kıyan E, Gemicioğlu B, et al. Turkish thoracic society consensus report: interpretation of spirometry. Turk Thorac J 2019;20(1):69-89.

8. Modrykamien AM, Gudavalli R, McCarthy K, Liu X, Stoller JK. Detection of upper airway obstruction with spirometry results and the flow-volume loop: a comparison of quantitative and visual inspection criteria. Respir Care 2009;54(4):474-479.

9. Albareda M, Viguera J, Santiveri C, Lozano P, Mestrón A, Bengoa $\mathrm{N}$, et al. Upper airway obstruction in patients with endothoracic goiter enlargement: no relationship between flow-volume loops and radiological tests. Eur J Endocrinol 2010;163(4):665-669.

10. Stevens JL, Constantinides V, Todd J, Meeran K, Christakis I, Tolley NS, et al. Do flow volume loops alter surgical management in patients with a goitre? Clin Endocrinol (Oxf) 2014;81(6):916-920.

11. Menon SK, Jagtap VS, Sarathi V, Lila AR, Bandgar TR, Menon PS, et al. Prevalence of upper airway obstruction in patients with apparently asymptomatic euthyroid multinodular goitre. Indian J Endocrinol Metab 2011;15(Suppl 2):S127-S131.

12. Thusoo TK, Gupta U, Kochhar K, Hira HS. Upper airway obstruction in patients with goiter studies by flow volume loops and effect of thyroidectomy. World J Surg 2000;24(12):1570-1572.

13. Sørensen JR, Hegedüs L, Kruse-Andersen S, Godballe C, Bonnema SJ. The impact of goitre and its treatment on the trachea, airflow, oesophagus and swallowing function. A systematic review. Best Pract Res Clin Endocrinol Metab 2014;28(4):481-494. 